\title{
Growing Household Credit Load Through the Prism of Social Perception, Credit, and Political Attitudes of Russians
}

\author{
Oleg Novikova ${ }^{\mathrm{a}}$ Nikita Kozlov
}

\begin{abstract}
${ }^{a}$ Associate Professor, Department of Political Science of Financial University, Moscow, Russia; OGNovikov@fa.ru
b 3rd-year student, Faculty of Social Sciences and Mass Communication, Financial University, Moscow, Russia; Kozlovn_54@mail.ru
\end{abstract}

\begin{abstract}
The year 2020 demonstrates another surge of civil non-conventional activism in the world due to the epidemiological situation and related government restrictive measures. In Russia, at the background of the "Corona-crisis" and falling real incomes, retail lending to households continues to proliferate, along with an increase in their overdue debt. The deteriorating economic well-being of Russians raises questions about the possibility of an increase in political protest behaviour of citizens and how much their readiness for it is affected by the deteriorating financial situation due to difficulties in paying off their loan obligations. The authors used the methods of cybermetric analysis and mass survey, examines the perception of the credit problem by Russians, their assessment of its causes and "culprits" (the state, banks and borrowers themselves). The paper also notes some trends of mutual conditionality at the individual level of credit attitudes of Russians, their financial prosperity and readiness to participate in various forms of pro-government and opposition political activity. The authors conclude that the most common conservative model of credit behaviour among Russians contributes to the latent deterioration of the subjective well-being of borrowers that not always leading to a decrease in credit payments. It, in turn, leads to a desire to share responsibility for these difficulties with creditors and the state and, probably, increases the readiness for protest activism.

Keywords: household credit debt; protest activity; credit attitudes; credit behaviour

JEL Classification: G41, G51

(c) Oleg Novikov, Nikita Kozlov, 2020
\end{abstract}

\section{Introduction}

In the modern age, rife with goods and services, large-scale socioeconomic inequalities persist, and opportunities for increased consumption remain very limited. Because of this contradiction between the growing supply and the unsuccessful demand (noted by the classic T. Malthus and later by many others), after the Second World War, the institution of consumer lending received rapid and previously unprecedented development, despite all the ambiguity of its perception by Western societies [Novikov, 2017, pp. 86-88]. However, the growth of consumer lending, although it stimulates the economy at the stage of recovery, also brings the business cycle closer to the point of overheating, which is usually caused by the again weakening demand from the negative contribution of credit debt to household income.

This perennial problem of credit cycles, in particular the growth of the debt burden of citizens and the subsequent growth of non-payments, becomes a predictor of political risk for the state and threatens the success of its economic policy [Kozlov, 2020, p. 56]. Today in Russia exists a situation of this risk evidenced by the statistics of the Bank of Russia for 2020. Despite the shocking decline in household lending by 44 and 30 per cent in April and May compared to 2019, in June, July, August and September, the corresponding dynamics showed an increase of 3, 13, 17, 22 per cent compared to with the same periods last year.

Thus, the COVID-19 pandemic did not affect the very trend of growth in the population's need 
for free cash. However, at the same time, the share of overdue debts is also growing, and (although in the total amount of debt it does not yet exceed 5 per cent) in the third quarter of 2020, in comparison with the second quarter, the share of overdue debt in the total amount of debt even decreased by 0.1 per cent. Still, in contrast to 2019 , over the same three months, this indicator decreased by 4.9 per cent. In absolute terms, the volume of delinquencies from the second to the third quarter increased from 810 billion rubles to 849 (+ 5.5 per cent), in 2019 over the same period the overdue debt decreased from 760 billion to 757 ( -0.4 per cent). ${ }^{1}$ It confirms that the factor of the pandemic crisis has seriously hit the solvency of citizens. ${ }^{2}$

In connection with this risk, ratings of Russian regions in terms of population debt load have become quite common. The debt load is calculated as the ratio of the total credit debt of the region's households to banks to the total income of its economically active population, usually for a year. Although such a comparison may provide some insight into the most problematic subjects of the country, it says little about the real burden of borrowers and its impact on the ability to maintain economic prosperity, since it does not take into account either real loan payments, or the cost of living in the region, or the number of borrowers.

Nevertheless, ratings such as, for example, the rating of the Agency "RIA Rating" ${ }^{3}$ or calculations of the All-Russia People's Front's project "For the rights of borrowers", ${ }^{4}$ attract the attention of ordinary citizens and various political actors to this problem using modern communication channels, primarily social media. The question arises: how

\footnotetext{
${ }^{1}$ The Bank of Russia, official site. Available at http://cbr.ru/ (Accessed 03.11.20).

2 This is also evidenced by the data for the 2nd quarter of 2020 : first, the fall in real disposable income of the population by 8 per cent compared to the same period in 2019; secondly, a significant reduction in household credit payments to banks in such regions as the Chechen Republic (22 per cent), Kaluga and Tyumen regions (14 per cent each); colossal growth of delinquencies - in the city of Sevastopol (17 per cent), the Republic of Crimea (11 per cent), the Udmurt Republic (8 per cent); and both of these trends are in the Kaliningrad region (16 and 33 per cent) and the Krasnodar Territory (17 and 7 per cent).

${ }^{3}$ Рейтинг регионов по закредитованности населения 2019. Агентство «РИА Рейтинг», 24.12.2019. Available at https://riarating.ru/infografika/20191224/630147980.html (Accessed 01.05.20).

${ }^{4}$ Карта кредитной и сберегательной активности домохозяйств РФ. Available at http://zapravazaemschikov.ru/ map/ (Accessed 12.08.20).
}

does society react to the growth of the population's credit burden in the face of the uncertainty of the future, which was clearly manifested in 2020 .

At the individual level of the problem, our focus shifts to how the individual borrower relates to the loan and the resulting debt: how this burden affects the emotional, cognitive and behavioural aspects of the individual. In this regard, the researchers cite different classifications of credit borrowers. For example, Yu.E. Muzhichkova singles out on active consumers (who often use credit services, assess their risks, and pay off debts on time), credit addicts (who are unable to objectively assess their capabilities, abuse new loans to pay off old ones, and often do not comply with their obligations), and conservative consumers (who use bank loans only in exceptional cases and seeking to pay off their debts as soon as possible) [Muzhichkova, 2015, p. 38].

Concerning debt, some borrowers will enthusiastically strive to repay it as soon as possible. In contrast, others, on the contrary, will experience demobilizing anxiety, fatigue and a sense of uncertainty about the future financial situation. The second model of behaviour can be defined as "financial threat". One of the tactics for overcoming the state of this threat is to maximize resources through a mode of the economy [Fiksenbaum, Marjanovic, Greenglass, 2017, pp. 129-131].

It is closely related to the influence of debt not only on the objective but also on the subjective dynamics of the socioeconomic well-being of a person. The deterioration of the latter, including through deprivation, can significantly affect the growth of political activity, including unconventional [Gurr, 1970]. Modern researchers confirm the applicability of the theory of relative deprivation for predicting social unrest, but only in the case of an increase in unemployment. In other cases, while reinforcing the resource theory of protest activism, scientists argue that the growth of social movements can be traced where, on the contrary, the economic situation shows improvements. However, separately objective indicators of the economy are often not able to give an idea of political risks from society, since they have little to do with individual perceptions of financial well-being [Vassallo, 2020, 58-63]. At the same time, a subjective assessment of a decrease in life satisfaction, which includes a much wider range of issues, in addition to economic ones, finds a posi- 


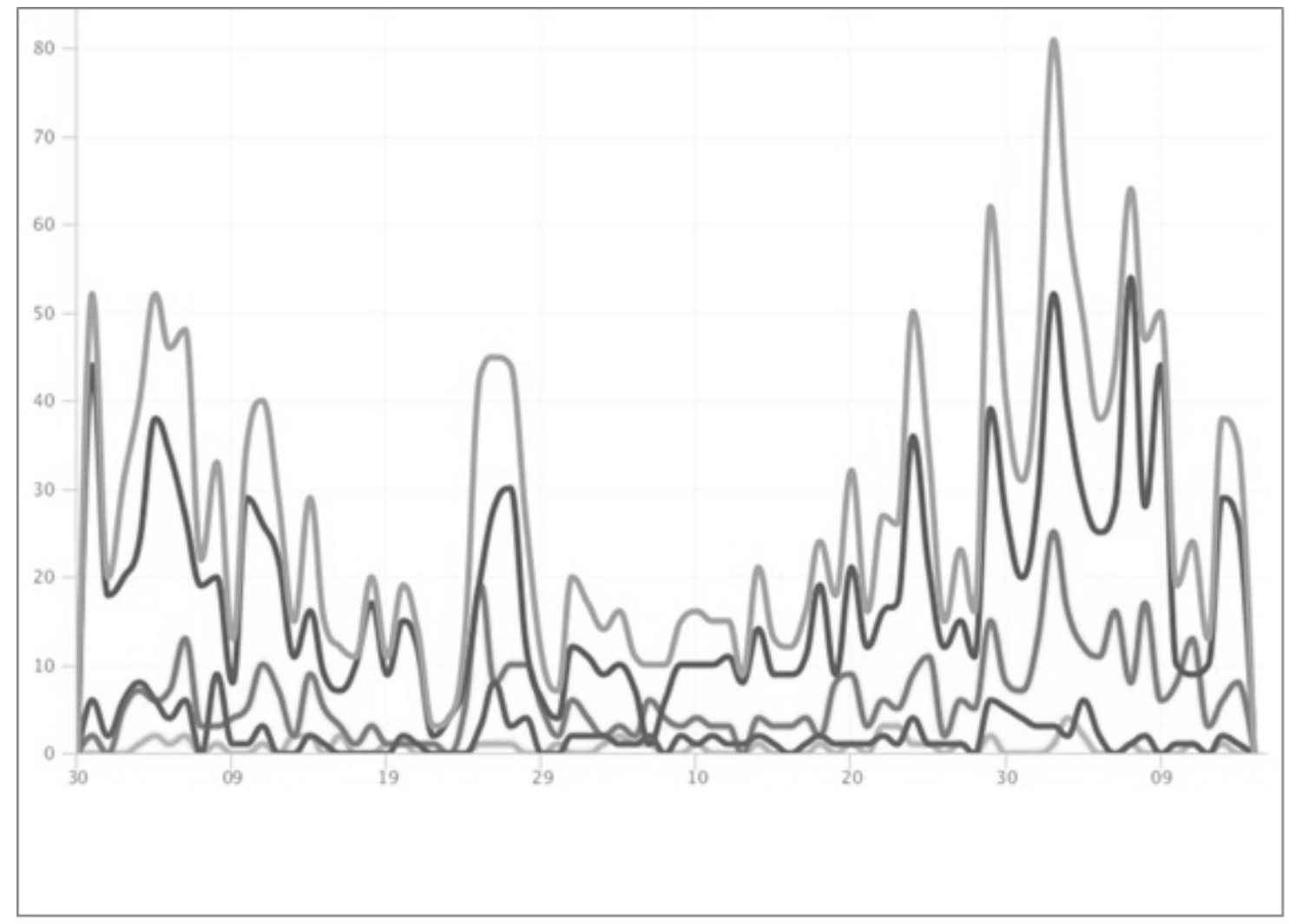

Figure 1. Dynamics of documents from 31.01 .20 to 14.04 .20 (no duplicates)

Source: IQBuzz.

tive relationship with the growth of civil protest actions [Witte, Burger, Ianchovichina, 2020, p. 135].

Thus, in order to understand how the situation of the indicated political risk of debt load can affect the political behaviour of citizens, this work will test the relevance of some of the above provisions, in particular, the perception of the problem of debt load at the social and individual levels, the impact of credit debt on the objective and subjective the financial situation of borrowers, citizens and the relationship between difficulties in repaying a loan and the political mood of borrowers.

\section{Methods of Research}

As unique research methods, the author used a cybermetric analysis of digital traces left by social media users on the issues of interest to us, as well as a method of a mass sociological survey conducted among adult residents of the city of Moscow, and subsequent correlation analysis.

Cybermetry was performed using IQBuzz software. In the course of the work, 5000 documents were unloaded, the content of which corresponded to the presence of keywords markers ("debt burden of the population", "bankruptcy of citizens", “debt hole”, “credit bondage", "credit slavery", etc.).

Two iterations of the documents were made, during which documents that did not correspond to the given problem were deleted, and the tonality of the documents was also affixed. After the first iteration, the request was adjusted, however, as a result of the second iteration, 2884 documents were saved (2055 - without duplicates), most of which are comments, posts on social networks and posts. The period for creating final sample documents is $01 / 31 / 2020-04 / 14 / 2020$. The tonality of the documents was set in relation to the authorities: negative messages - which expressed a negative perception of the authorities of the Russian Federation in connection either with the indicated problem or with measures taken to resolve it; positive - contained the approval of the modern Russian authorities; mixed - did not allow to determine the pole of the given assessment; neutral unambiguously - stated the facts, had no emotional colouring or did not mention the authorities at all.

The distribution of messages in dynamics we showed in Figure 1. The largest number of messages fell on the periods: the 31st of January - 
the 12th of February (there is no pronounced topic, few negative documents), 25-27 February (amendment to hold an all-Russian vote and the estimated date, negative in the unwillingness to vote for "rewriting the constitution" and support the authorities who have driven people into a "debt hole"), 10-15 March ("zeroing the presidential terms - why not zeroing citizens' loans"), from the 20th of March (about self-isolation, nonworking days that drive people into a "debt hole"; the delusion that the state is obliged to hold a credit amnesty, dissatisfaction with refusals in credit vacations, and if approved, the accrual of interest for their period $=>$ the measures taken are ineffective, they drive people into credit bondage: "all the measures taken are a postponed debt hole for representatives of small and medium-sized businesses, for of many people").

In terms of sentiment, the messages in the sample were distributed in the following ratio: neutral -67.4 per cent, negative -22.9 per cent, mixed -7.3 per cent, positive -2.4 per cent. Moreover, more than 50 per cent of all negative documents fell on the period from the 20th of March to the 14th of April.

More than 12 million users could see these messages (2055) - the coverage of messages was 12091582 people.

Also in the period from 27.09. until 05.10. In 2020, a massive sociological survey was conducted. The distribution of the questionnaire was carried out in social networks: VKontakte and Facebook by a random method through private messages and various community groups. The sample was formed with two restrictions: all respondents had to be of legal age and have a permanent registration in Moscow (to be able to vote in the Moscow elections). The total sample of respondents was 235 people. Among them -83 per cent are women, and 17 per cent are men.

By age groups: $18-24$ (8 per cent), 25-34 (35 per cent), 35-44 (41 per cent), $45-59$ (15 per cent), 60 and more (1 per cent). 84 per cent of respondents have completed higher education. Thus, the sample does not pretend to be representative in the classical sense, but on the whole meets the set tasks of the work, in particular, the search for correlations between different socioeconomic and political indicators.

Each respondent had to go through several blocks of questions: to assess the degree of agree- ment with statements about a loan, about readiness for forms of political activity aimed both at supporting the authorities and against it, leaving some information about themselves, in particular, assessing their economic well-being, answering the presence or absence of current outstanding loan obligations, as well as expectations of difficulties in repayment.

The loan statements proposed for assessment were divided into 5 groups: 3 statements each reflecting an optimistic view (for example, "Loan is a convenient banking service that saves time" or "Having a loan encourages me to work more actively") - credit optimism - and pessimistic look ("For me, credit is an unbearable burden and burden" or "Burdening oneself with credit is possible only in case of extreme despair") - credit pessimism.

Three other groups included one statement each, indicating the responsibility of banks, the borrower and the state ("The main purpose of a loan is to tempt a person to buy and make a person dependent on the bank", "People who take out a loan drive themselves into credit bondage", "The Russian authorities are responsible for the credit problems of their citizens").

The block of questions for assessing the willingness of respondents to participate in political activities in support of or against the current government included such forms of participation as voting in elections, participation in the work of public organizations, participation in (un) sanctioned rallies, financial assistance to public organizations, signing collective petitions, appeal to the authorities and politicians, etc.

To measure the expectations of respondents of varying degrees of difficulty in repaying the current loan, as well as questions to assess the objective and personal financial situation of the respondent, we used the formulations from the VTsIOM (Russian Public Opinion Research Center)-SPUTNIK survey. ${ }^{5}$

To search for relationships between variables such as the expectation of credit difficulties, credit pessimism and optimism, the assignment of re-

\footnotetext{
${ }^{5}$ How do you assess your ability to repay the current loan? (Kak Vy otsenivayete svoi vozmozhnosti po pogasheniyu tekushchego kredita?). VTsIOM (ВЦИОМ), 19.11.2017. https://wciom.ru/ trzh/print_q.php?s_id=60\&q_id=3375\&date=19.11.2017 (Accessed 11.09.2020).
} 
sponsibility to lenders, borrowers and the state, objective and subjective levels of financial security (income), the willingness to support the authorities and the readiness to oppose the authorities, a pair correlation analysis. It made possible identification of some trends and indicated further directions of research.

Among those surveyed, 37 per cent stated that they are currently paying off outstanding loans (consumer, auto, mortgage). Among them, 56 per cent (or 21 per cent of the entire sample) stated their expectations of loan repayment without difficulties or with little difficulty. 40 per cent of borrowers (15 per cent of the total number of respondents) expect that they will be able to repay the loan only with great effort or will not be able to do it at all.

\section{Results}

As a result of the analysis of the discourse in the sample of messages for the period from the 31 st of January to the 14th of April, 2020, it was possible to come to several conclusions. Today, the problem of citizens' debt burden is latent in public discourse on social media, that is, it is rarely discussed separately from other problematic news events, such as the "oil war", amendments to the Constitution, economic support of business and the population, etc.

The situation with the population's debt burden by itself does not cause wide public discussion on social media and is rarely distinguished by a pluralism of opinions regarding the negative consequences of the credit burden, which, from the author's point of view, can be explained by the general consensus in assessing credit for the population (consumer, mortgage) as a negative and undesirable instrument "driving you into debt" or "credit bondage". Closely related to this is a wide range of comments and entries, the content of which clearly indicates a negative attitude towards the capitalist economic model and a vast demand for an equitable distribution of wealth, which is in stark contrast to credit and lending.

Indeed, as of September 2019, 76 per cent of Russians believe that a loan is permissible if absolutely necessary, while 82 per cent believe that the loan must be repaid under any circumstances. The state should always help the borrower in case of difficulties with payments (22 per cent) and in exceptional cases (55 per cent). ${ }^{6}$

The results of the authors' survey of Moscow residents are quite consistent with these figures. Thus, 63 per cent of the respondents to one degree or another agree that it is worth taking out a loan only in cases of extreme despair. The same 63 per cent - among actual borrowers, however, the answers differ markedly between those expecting difficulties in repayment and no: among the former, $80 \%$ agree with the statement, among the latter- only 46 per cent. And the opposite statement about credit as a service that saves time is not supported by 67 per cent of all respondents (among actual borrowers -63 per cent).

And 38 per cent agree with the fact that in Russia, credit has become the only opportunity to purchase the desired product "here and now" (47 per cent do not agree). The respondents with current loan obligations agreed with this in 62 per cent of cases, which suggests that the financial possibilities of Moscow borrowers are very limited. Depending on the expectations of difficulties in repayment, opinions were practically not divided on this issue.

Also, 68 per cent do not agree that loan obligations encourage them to work more actively (only 18 per cent agree). Interestingly, among those with an outstanding loan, the number of those who support this statement increases to 31 per cent, and among those awaiting credit problems - there is also 31 per cent against 35 per cent among selfconfident borrowers. That is, despite individual credit experience, the majority in any category of borrowers do not find credit as a motivating tool.

The “culprits” of Russians' growing debts are different in the perception of social media users. These are the debtors themselves, who take loans for a new car or the latest smartphone model, these are banks with MFIs ready to "rip it off", this is the state that has brought the country's economy to a situation where citizens are forced to go into unbearable credit debts. And although the latter point of view on the subject responsible for this problem prevails in social media quantitatively, in many cases the inseparability of the interests of financial capital from the highest ranks of state power is emphasized.

\footnotetext{
${ }^{6}$ Credits: Attitudes and Practices. FOM (Kredity: ustanovki i praktiki. FOM). 20.09.2019. https://fom.ru/Ekonomika/14260 (Accessed 08.05.20).
} 


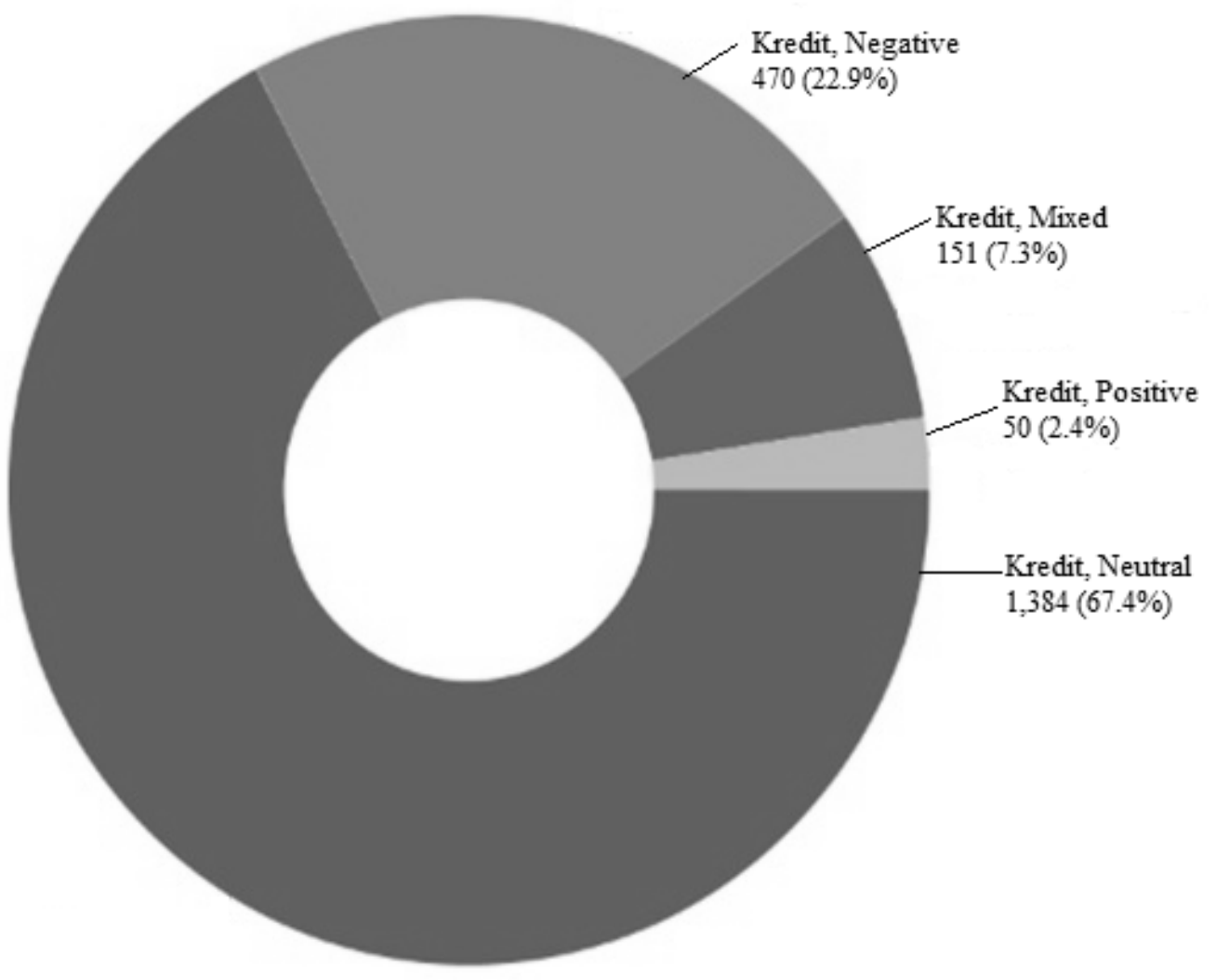

Figure 2. Distribution of Documents by Sentiment (Without Duplicates)

Source: IQBuzz

According to the results of the cybermetric analysis, the messages containing the connection between the problem of Russian debt load and the guilt and ineffectiveness of federal politicians make up almost a quarter of the sample (see Figure 2).

The negative messages were of the following nature: the presentation of the high debt load of the population as one of the results of Vladimir Putin's rule expressing a negative assessment of the latter; hatred of state political initiatives (for example, voting on amendments) due to poverty of the population (debt load and an increase in the number of bankruptcies as its indicators); expression of dissatisfaction with the insufficiency and "cunning" of the credit holidays; the attitude to self-isolation measures as a push into a credit hole; the demands of the left opposition to the authorities to introduce a credit amnesty for the population, the ONF's call to execute the President's decree on credit vacations, etc.
A survey conducted among Moscow residents confirms some of the findings of the analysis of subject discourse in social media. Figure 3 shows how the assessments of all respondents were distributed for each of the "culprits" of the population's credit problems: the statement about selfish banks (73 per cent) received the greatest agreement, followed by the borrowers themselves (70 per cent) and government authorities (58 per cent).

Classification of respondents depending on the presence or absence of outstanding loans and expectations regarding the possibility of repayment will reveal some more features. Thus, the direct borrowers among the respondents, regardless of the expected credit difficulties, were less confident when assessing the statement about their responsibility for the assumed credit burden: 24 per cent expressed absolute agreement, 48 per cent rather agree. Nevertheless, such a high awareness of their choice (72 per cent) as a risk of "enslavement" clearly speaks of the prevalence among Muscovites of a conservative model of 


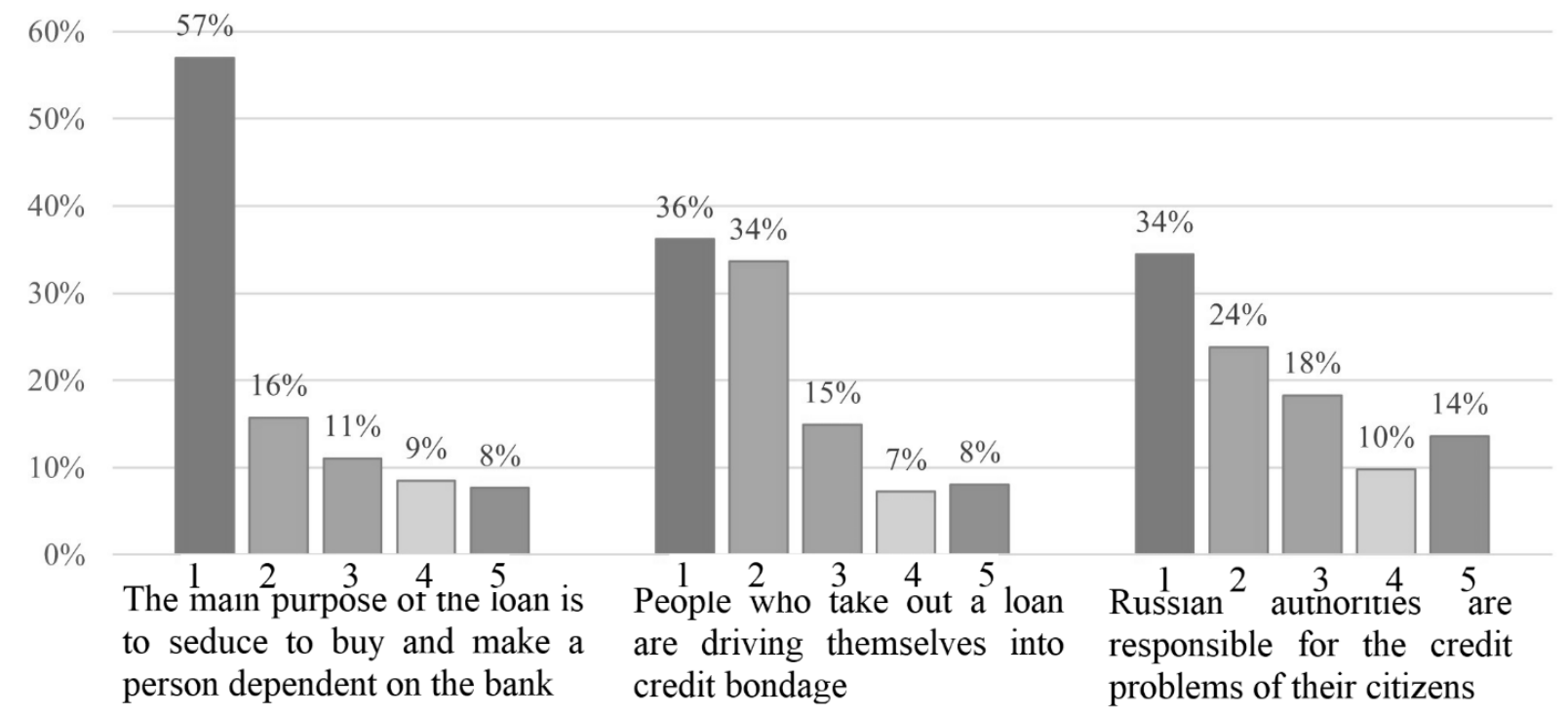

1 Absolutely agree 2 Rather agree 3 Not sure 4 Rather disagree 5 Strongly disagree

Figure 3. Distribution of Answers According to Statements About the Subject of Responsibility for Credit Debts of Russian Citizens ( $N=235)$

Source: The authors.

consumption of credit services, in which credit is most undesirable, and the culture of fulfilling the obligations assumed is indisputable.

At the same time, there is a very striking difference between the assessments of respondents-borrowers with optimistic and pessimistic expectations of debt repayment regarding the "fault" of banks and the state. Among optimists, 57 per cent and 49 per cent agree that creditors and the Russian authorities are responsible for credit problems, respectively, while debtors who are pessimistic about their ability to repay a loan agree with this in 89 per cent and 74 per cent of cases.

At the same time, the difference between the respondents' assessments is quite striking - this proves that, when realizing the difficulties of their situation, people tend to share responsibility with others, and targeted work with this category of borrowers requires special attention from both credit institutions and government officials.

The results of the correlation analysis between the above variables also confirm some of the observations made (see Table 1). For example, the relationships between the borrower's expectations of credit difficulties and their attitudes toward loans turned out to be statistically significant: a fairly strong positive relationship $(r=0.487)$ of higher expectations of debt repayment problems was found with credit pessimism, and, conversely, negative, but weaker - optimistic $(r=-0.227)$.

There is also a significant (with a probability of 99 per cent) average positive dependence of the expectations of problems with loan repayment and "blaming" banks $(r=0.349)$ and a significant 95 per cent average direct correlation of the same expectations of difficulties and the blaming of the Russian authorities $(\mathrm{r}=0.256)$.

Credit optimism is inversely related to the imposition of responsibility on banks $(r=-0.278)$ and the borrower $(r=-0.182)$ with a statistical error of no more than 1 per cent. Also, at the level of the trend, he has a positive relationship with the financial situation, in particular, with a probability of 95 per cent, there is a significant correlation between an optimistic view of credit and the objective financial situation of the respondent $(r=$ 0.159). It makes it possible to assume that the more secure a person is, the more positive aspects he will find for himself in a loan.

In turn, credit pessimism has significant, close to average, positive links with the assignment of responsibility to all three subjects and with a general readiness for protest political behaviour $(r=0.133)$ and an inverse relationship with the respondent's financial situation. It tells us that the more a person considers credit unacceptable, burdensome. Still, the only chance to acquire an 


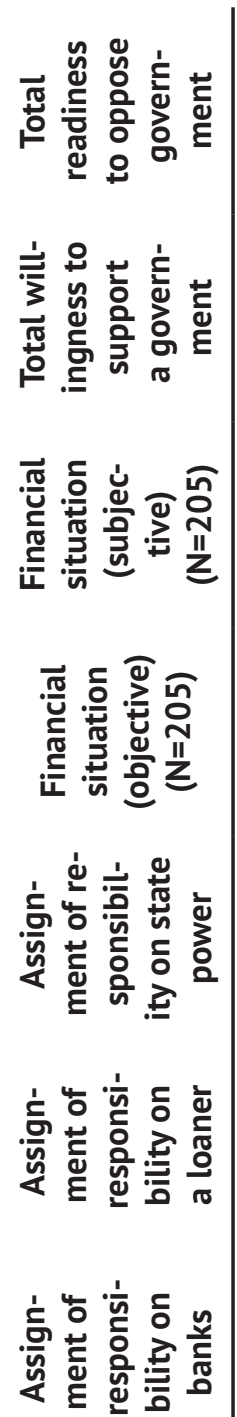

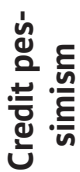

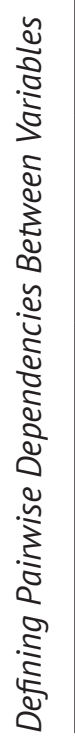

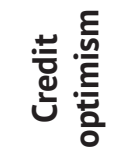

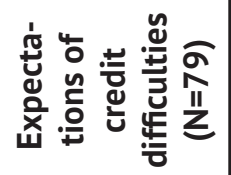

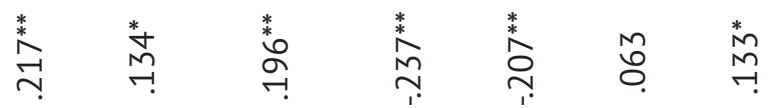

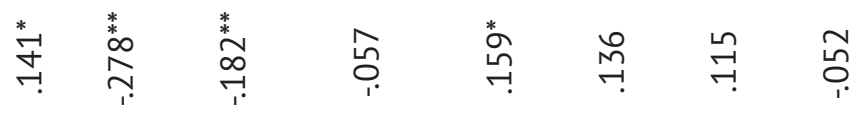

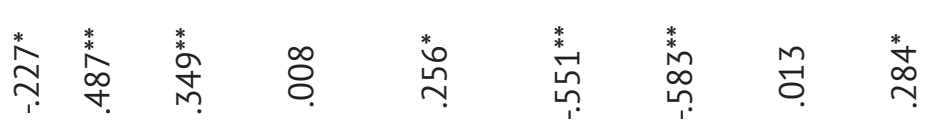

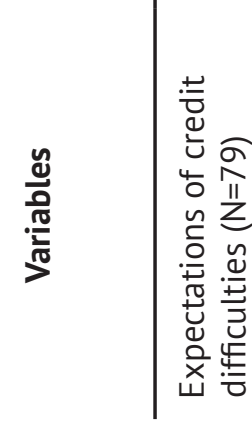

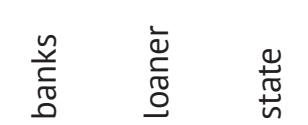

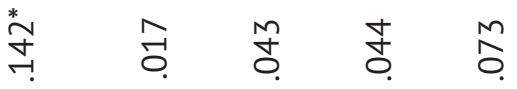

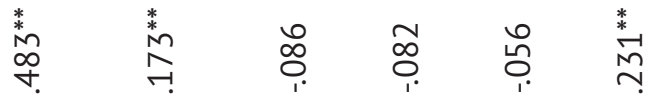

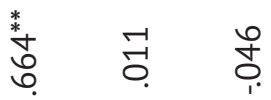

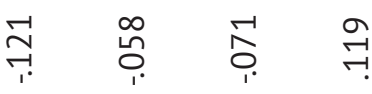

$\stackrel{*}{\circ}$

$\stackrel{*}{\stackrel{*}{+}} \stackrel{\stackrel{+}{7}}{?}$
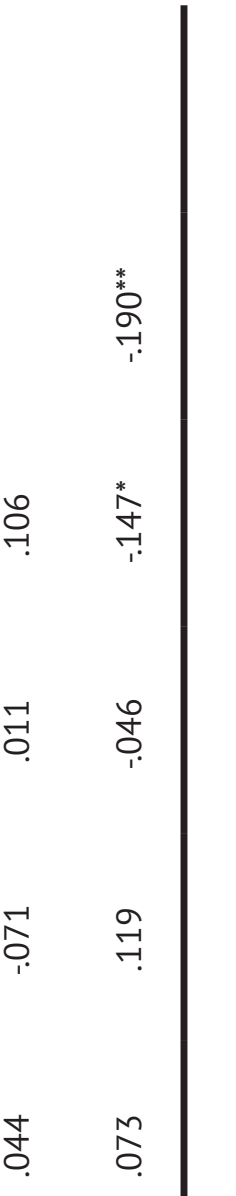


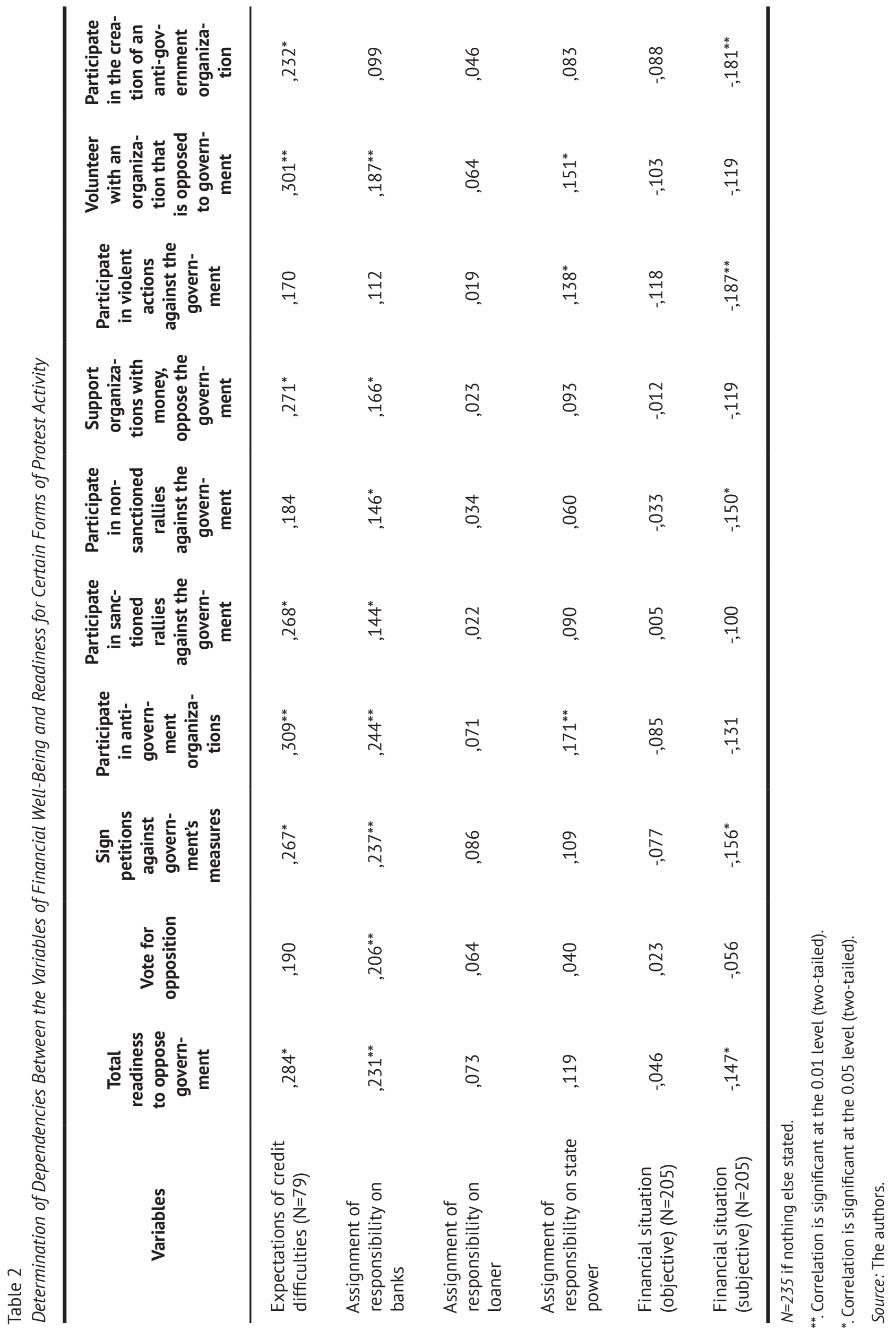


expensive product, the more he will blame banks, the state, and even in fewer cases, himself for the credit risk taken.

Such a person will be more inclined to take actions to express his lack of power support. And, most importantly, more often this position will be characteristic of people with credit difficulties and poorer financial position (a strong inverse correlation was revealed between the expectation of more serious credit problems and higher financial status, and this relationship with the respondent's objective material position $(r=-0.551)$ slightly less compared to his subjective rating $(\mathrm{r}=-0.583)$ ).

Speaking about the possible impact of credit debt on the political behavior of citizens, we immediately note that no statistically significant correlation could be established between the variables of credit and financial issues and the willingness to support the current government in various ways (this factor had the highest correlation with credit optimism $(r=0.115)$ ).

However, some tendencies were established by referring to the variable of readiness to oppose the government and its policies through various forms of political activity (see Table 2). So, this factor in total terms with a probability of 99 per cent positively correlates with the respondent's assignment of responsibility for credit debts to banks wishing to make the borrower dependent on themselves $(r=0.231)$. At the same time, with an error of 5 per cent, the average direct relationship with the expectations of difficulties in repaying a loan $(r=0.284)$ and a weaker inverse correlation with the subjectively estimated favourable financial situation $(\mathrm{r}=-0.147)$ are significant. It follows from this that the respondents expect the greater difficulties with their credit debt, and the worse they assess their financial situation, the higher their readiness as a whole to oppose the government.

Let's see how the factors we are considering affect certain forms of readiness for protest activity. The strongest direct correlations with the expectations of credit problems - the readiness of respondents to such forms of non-support of the authorities as participation in the work of public and political organizations opposing the government $(r=0.309)$, work in such organizations as a volunteer $(r=0.301)$, as well as financial support for such organizations $(\mathrm{r}=0.271)$, participation in anti-government sanctioned rallies $(r=0.268)$ and signing collective petitions and appeals against government measures $(r=0.267)$. The subjective material situation of the individual, which is interesting, demonstrates a lower in strength, but statistically significant negative relationship with the readiness for various forms of expression of disagreement with the state authorities: with violent street actions $(r=-0.187)$ and with participation in the creation of a public organization $(r=-0.181)$, as well as signing petitions $(r=-0.156)$ and participation in unauthorized rallies $(r=-0.150)$.

But the dependences of the respondent's objective financial position on any form of protest activity are insignificant. The same can be noted regarding the degree of agreement with the fact that the borrower is driving himself into "credit bondage".

At the same time, the assignment of responsibility to banks showed as many as four significant (with a probability of 99 per cent) correlations with such forms of non-support to the government as participation in the work of public and political organizations $(r=0.244)$, signing petitions $(r=0.237)$, voting in elections for opposition $(r=$ $0.206)$ and work as a volunteer $(r=0.187)$. It means that the more the respondents agreed that a loan is a means of making a person dependent on the bank, the more people among them were willing to participate in organizations independent of the government, sign collective letters against the government and vote for the opposition in elections.

At the 95 per cent level, this factor also affects other forms of protest, but the correlation coefficient is even lower there. According to the author, such a connection between attitudes towards credit and readiness to oppose the authorities in various forms can be explained by a vivid negative interpretation of unfreedom - the dependence contained in this statement, since the relationship of credit debt can be directly associated with forced restrictions, so unacceptable opponents of state authorities.

The respondents are more inclined to believe that it is the authorities who are responsible for the population's credit problems, are more willing to work in organizations that oppose the course of the official authorities $(r=0.171)$, to a slightly lesser extent - to work as a volunteer $(r=0.151)$ or to participate in violent protests $(r=0.138)$. 


\section{Conclusions}

As a summary of the work, let us pay attention to some observations based on the analysis of empirical data. The analysis of the discourse clearly showed that the problem of the growth of the credit burden of the population and the difficulties encountered in repaying loans does not go unnoticed in social media, and, although it is not a central topic of discussion, it is regularly updated in a variety of news items.

On the Internet, in the vast majority of cases, the loan is perceived extremely negatively and is often associated with expressions such as "debt hole" and "credit bondage". This, as well as the agreement of 73 per cent of Muscovites surveyed that the task of a loan is to make a person dependent on a bank, speaks of the attitude of citizens towards the institution of lending as a selfish mechanism of encumbrance and the following restrictions. Due to the high awareness of the need to repay debts (82 per cent of Russians believe that loans must be repaid in any situation), loans, which, according to 63 per cent of Moscow borrowers, are permissible only in hopeless cases, do not stimulate borrowers to earn more money, but rather activate savings a model of behaviour or, more simply, a model of the economy in the context of a decrease in real disposable income, which negatively affects the subjective assessment of an individual's financial situation.

However, the existence of a current loan in itself is not always associated with a poor financial situation (no significant connection was found here). And this is explained by the fact that 56 per cent of those surveyed who turned out to be valid borrowers expect that they will easily or with little difficulty repay their loan, while $40 \%$ are preparing to face great difficulties or will not be able to repay the debt at all. And it was precisely between this factor and the respondent's material position that a very strong inverse correlation was found: the greater credit difficulties an individual expects, the worse he estimates the level of his economic wealth.

Correlation analysis also revealed an important trend that answers one of the research questions: indeed, the expectation of serious problems with loan repayment directly affects the growth of protest sentiments among such borrowers, expressed in a higher readiness to participate in various forms of political activity aimed at opposing the government and its policies.

Interestingly, the strongest significant correlation was found with the willingness to participate in and volunteer in anti-government public and political organizations. This fundamentally does not confirm the theory of protest political participation, provided with appropriate time, material and other resources, since credit difficulties in fact mean an insufficient amount of resources for engaging in social and political activities within the organization after all the costs of overcoming the negative consequences of credit.

It should be noted, however, that willingness to participate does not always translate into participation itself. However, in this case, it also becomes unclear what is the reason for the lack of a more noticeable direct connection between credit difficulties and voting for opposition candidates, because voting as a voter is a much less costly event. However, the answer to this and other questions has yet to be given with the help of new research, not limited to a sample of residents of a very specific political life of the capital.

This work also demonstrated that the perception by the population of the current Russian economic model as unfair is valuable for building the entire economic policy in the country, in particular with regard to the redistribution of financial resources between business entities, which is connected with the memory of a financially stable and much fairer memory preserved in the minds of some part of the population about the life in the USSR.

Analysis of the discourse in social media has also established that credit problems have their "creators", those subjects that, in the opinion of citizens, are to blame for their existence. These include, firstly, lenders, that is, first of all, banks and MFOs, secondly, the borrowers-households themselves, and thirdly, government authorities that did not prevent or even contributed to the acceleration of the debt burden of the Russian population.

On the Internet, because of its specificity as a platform for expressing opinions, in a quarter of all cases of discussion of the problem of Russians' debt burden, responsibility is laid on the state and its official authorities. Less often - on other subjects. A mass survey conducted among social media users from Moscow showed that in the 
greatest number of cases, citizens agree that, first of all, a loan is needed in order to tempt people to buy and, as a result, make a person dependent on a bank (73 per cent).

Also, the overwhelming majority of those surveyed agree that the borrower condemns himself to a loan. Among real borrowers, there are even a little more of them, which, along with the prevailing negative attitudes towards credit, characterizes the prevailing conservative model of credit behaviour of Muscovites, however, when using this information, it is worth remembering that the declared attitudes are not always implemented in behaviour, as evidenced by the "Lapierre paradox" [Davydenko, 2014, p. 26]. A little less often, Moscow respondents agreed that the credit problems of citizens are the responsibility of the state authorities (58 per cent); nevertheless, their number is significant.

Among those who expect great difficulties in repaying their loans, the number of those who impose responsibility on banks and the state is significantly higher, which is consistent with the fact that people who are tolerant of credit are more inclined to write off responsibility for failures on others or bad luck [Lebiedev \& Gordyakova, 2016, p. 80]. Despite the clarified link between blaming the lender and the authorities with credit pessimism and the expectation of credit problems, the question remains: is there a relationship between these characteristics and an individual's trust in banks, MFIs or key political institutions of the state.

The answer will make it possible to ascertain to what extent the shifting of responsibility to the lender and the state will contribute to a decrease in confidence in them in the event of an increase in problems with loan payments. Closely related to this issue is the tendency, confirmed in the Moscow sample, that people who are inclined to treat credit as a means of driving the bank into "credit bondage" express a greater readiness to engage in political activity that opposes the official authorities.

Speaking about the costs of work that influenced the result, it should be noted that, like cybermetry, and the mass survey was conducted at a time of growing uncertainty and general irritation with the pandemic situation and its economic consequences, which could affect the respondents' assessments of their ability to repay the loan. and readiness for one form or another of political activity, as well as on the emotional state of social media users.

This allows us to regard the presented results as reflecting not only the attitude of Russians to credit and their political moods, but also the reaction of the population to the current events of 2020, which challenge the maintenance of the previous quality of life, and therefore, as the world experience of recent years shows, they are also "fuel "For the flaring fire of social protests [Shek, 2020, p. 633]. Therefore, in order to confirm or deny the relevance of these results for the conditions of a more predictable reality, the following measurement of public mood should be carried out.

A second note for further work could be the development of a broader set of statements to assess credit optimism and pessimism, as well as the responsibility that citizens, creditors and authorities place upon themselves. In addition, the sample of respondents should be expanded both quantitatively and by expanding the regional coverage of respondents in order to neutralize the specifics of the social dynamics of the megalopolis, which is Moscow.

Directions for further research in this problem area can be deepening knowledge about the influence not only of citizens' attitudes towards credit but also to such related categories as debt and interest rate, that is, the price of a loan, as well as the development of specific models of political behaviour depending on the degree of credit load and (not) incoming difficulties in its repayment. The study of these issues will allow us to form a more detailed picture of the mutual influence of credit relations, in which the individual is and can potentially be, and his political moods and (not) readiness for various forms of participation in politics.

$* * *$

This study has shown that the responsibility of the borrowers themselves for the loans they have taken and their perceived obligation to repay debts in any situation puts people in a disappointing and frustrating position when credit difficulties arise.

It, firstly, is reflected in the fact that the deterioration of subjective and objective material well-being, apparently, is possible even 
before the physical impossibility of repaying the loan, which is manifested in statistics in a reduction in loan payments and an increase in overdue debt, since a conservative borrower will continue to bear his credit obligations to the bank, even if this will lead to a decrease in the quality of his life until the subsistence level is

reached; secondly, the difficulties in repaying the loan by Muscovites, despite the routine continuation of payments, probably contribute to the desire to share responsibility for these problems with the bank or the state, which in turn is expressed in the increased readiness for protest political activity.

\section{References}

Bahadir B., De K., Lastrapes W.D. (2020). Household Debt, Consumption and Inequality. Journal of International Money and Finance.

Bloise F., Chironi D., Pianta M. (2020). Inequality and voting in Italy's regions. Territory, Politics, Governance. doi: 10.1080/21622671.2020.1837219.

Bor A. (2019). Evolutionary leadership theory and economic voting: Warmth and competence impressions mediate the effect of economic perceptions on vote. The Leadership Quarterly. doi: 10.1016/j.leaqua.2019.05.002.

Cardaci A. (2018). Inequality, household debt and financial instability: An agent-based perspective. Journal of Economic Behavior \& Organization, 149, pp. 434-458.

Dassonneville R., Lewis-Beck M. S. (2019). Inequality and party support: positional economic voting or a new dimension of valence? Regional Studies, pp. 1-10.

Fiksenbaum L., Marjanovic Z., Greenglass E. (2017). Financial threat and individuals' willingness to change financial behavior. Review of Behavioral Finance. Vol. 9. No. 2. P. 128-147. DOI 10.1108/RBF-09-2016-0056.

Gagarina M.A. (2018). Sense of debt and debt behavior of Russians with different levels of financial literacy [Chuvstvo dolga i dolgovoye povedeniye Rossiyan s razlichnym urovnem finansovoy gramotnosti. Institut psikhologii Rossiyskoy akademii nauk. Sotsial'naya i ekonomicheskaya psikhologiya]. Institute of Psychology of the Russian Academy of Sciences. Social and Economic Psychology, 3(3)(11), 179-198.

Gurr T. (1970). Why Men Rebel. Princeton: Princeton University Press.

Davydenko I. G. (2014). Determinants of the population's credit behavior in the context of the consumer lending market development [Determinanty kreditnogo povedeniya naseleniya $\mathrm{v}$ usloviyakh razvitiya rynka potrebitel'skogo kreditovaniya. Obshchestvo: politika, ekonomika, parvo]. Society: politics, economics, law, 3, $22-27$.

Kern A., Amri P. (2020). Political credit cycles. Economics \& Politics. doi:10.1111/ecpo.12158.

Kowalewski M. (2020). Street protests in times of COVID-19: adjusting tactics and marching “as usual.” Social Movement Studies, 1-8.

Kozlov N.A. (2020). Political risks of consumer lending dynamics in Russia (analysis of federal statistical indicators) [Politicheskiye riski dinamiki potrebitel'skogo kreditovaniya v Rossii (analiz obshchefederal'nykh statisticheskikh pokazateley). Samoupravleniye]. Self-government, 3 (120), 51-57.

Lebedev A.N., Gordyakova O.V. (2016). Sense of debt and types of credit and debt behaviour. [Chuvstvo dolga i tipy kreditno-dolgovogo povedeniya. Prikladnaya yuridicheskaya psikhologiya]. Applied legal psychology. 4, 74-82.

Muzhichkova Yu. E. (2015). Psychology of everyday ideas about debts and loans [Psikhologiya obydennykh predstavleniy o dolgakh i kreditakh. Gumanitarnyye nauki. Vestnik Finansovogo universiteta]. Humanitarian sciences. Financial University Bulletin, 4 (20), 37-44.

McNair S., Summers B., de Bruin W. B., Ranyard R. (2016). Individual-level factors predicting consumer financial behavior at a time of high pressure. Personality and Individual Differences, 99, 211-216.

Nofsinger J.R. (2012). Household behavior and boom/bust cycles. Journal of Financial Stability, 8(3), 161-173.

Novikov G.E. (2017). Essay on the history of consumer credit [Ocherk istorii potrebitel'skogo kredita. Ekonomicheskaya sotsiologiya]. Economic sociology. 18 (1), 80-95.

Osipov A.V. (2015). Debt behaviour of households: typology and parameters [Dolgovoye povedeniye domokhozyaystv: tipologiya i parametry. Gumanitarnyye nauchnyye issledovaniya]. Humanities research. http://human.snauka.ru/2015/09/12661 (Accessed 10/10/2020).

Porokhovsky A.A. (2014). Debt problem as a phenomenon of the XXI century: monograph [Dolgovaya problema kak fenomen XXI veka: monografiya]. Moscow: MAKS Press. 
Shek D. (2020). Protests in Hong Kong (2019-2020): A Perspective Based on Quality of Life and Well-Being. Applied Research in Quality of Life, 15, 619-635.

Szewczyk J., Crowder-Meyer M. (2020). Community Income Inequality and the Economic Gap in Participation. Political Behavior. doi: 10.1007/s11109-020-09621-6.

Theiss M., Kurowska A. (2019). Being denied and granted social welfare and the propensity to protest. Acta Politica, $54,458-478$.

Tokunaga H. (1993). The use and abuse of consumer credit: Application of psychological theory and research. Journal of Economic Psychology, 14(2), 285-316.

Turdaliev N., Zhang Y. (2018). Household debt, macroprudential rules, and monetary policy. Economic Modelling. doi: 10.1016/j.econmod.2018.09.001.

Vassallo F. (2020). After the crisis: political protest in the aftermath of the economic recession. Comparative European Politics, 18, 45-72.

Weiss H. (2014). Homeownership in Israel: The Social Costs of Middle-Class Debt. Cultural Anthropology, 29(1), 128-149.

Wilford A.M. (2020). Understanding the Competing Effects of Economic Hardship and Income Inequality on Voter Turnout. Politics \& Policy. doi: 10.1111/polp.12344.

Witte C.T., Burger M.J., Ianchovichina, E. (2020). Subjective Well-Being and Peaceful Uprisings. KYKLOS, 73(1), $120-158$.

Xiao J.J., Yao R. (2020). Debt types and burdens by family structures. International Journal of Bank Marketing, 38(4), 867-888.

\title{
Рост кредитной нагрузки на домохозяйства через призму социального восприятия, кредитоспособности и политических взглядов россиян \\ Олег Григорьевич Новиков ${ }^{\mathrm{a}}$ Никита Козлов
}

\author{
а Доцент кафедры политологии, Финансовый университет, Москва, Россия; OGNovikov@fa.ru \\ ' студент 3-го курса факультета социальных наук и массовых коммуникаций, Финансовый университет, \\ Москва, Россия; Kozlovn_54@mail.ru \\ (c) Олег Новиков, Никита Козлов, 2020
}

Аннотация. 2020 год демонстрирует очередной всплеск гражданской нетрадиционной активности в мире из-за эпидемиологической ситуации и связанных с этим государственных ограничительных мер. В России на фоне «корон-кризиса» и падения реальных доходов розничное кредитование домашних хозяйств продолжает расти вместе с увеличением их просроченной задолженности. Ухудшение экономического благосостояния россиян вызывает вопросы о возможности усиления политического протестного поведения граждан и о том, насколько на их готовность влияет ухудшение финансового положения из-за трудностей с погашением своих кредитных обязательств. Авторы использовали методы киберметрического анализа и массового опроса, исследуют восприятие кредитной проблемы россиянами, их оценку причин и «виновников» (государство, банки и сами заемщики). В статье также отмечаются некоторые тенденции взаимной обусловленности на индивидуальном уровне кредитного отношения россиян, их финансового благополучия и готовности участвовать в различных формах проправительственной и оппозиционной политической деятельности. Авторы приходят к выводу, что наиболее распространенная консервативная модель кредитного поведения россиян способствует скрытому ухудшению субъективного благополучия заемщиков, что не всегда приводит к снижению кредитных выплат. Это, в свою очередь, приводит к желанию разделить ответственность за эти трудности с кредиторами и государством и, возможно, повышает готовность к протестной активности.

Ключевые слова: кредитная задолженность населения; протестная деятельность; кредитное отношение; кредитное поведение 